\title{
Expression of High Affinity Interleukin-4 Receptors on Human Renal Cell Carcinoma Cells and Inhibition of Tumor Cell Growth In Vitro by Interleukin-4
}

\author{
Nicholas I. Obiri, ${ }^{\star}$ Gilda G. Hillman, ${ }^{\star}$ Gabriel P. Haas, ${ }^{\ddagger}$ Sudha Sud, ${ }^{\star}$ and Raj K. Puri* \\ *Division of Cytokine Biology, Center for Biologics Evaluation and Research, Food and Drug Administration, Bethesda, Maryland

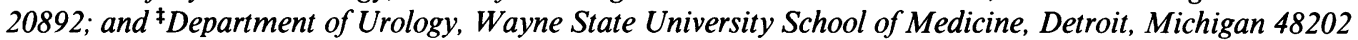

\begin{abstract}
Previously, Puri et al. (Puri, R. K., M. Ogata, P. Leland, G. M. Feldman, D. Fitzgerald, and I. Pastan. 1991. Cancer Res. 51:3011-3017) have demonstrated that murine sarcoma and colon adenocarcinoma cells express high affinity interleukin-4 receptors (IL-4R) which are internalized after binding to a chimeric ligand consisting of IL-4 and Pseudomonas exotoxin. In the present study, we have tested primary cultures of human renal cell carcinoma ( $R C C)$ cells, generated from tumor specimens obtained after nephrectomy, for the expression of IL-4R and their modulation by IL-4. By using iodinated IL-4 in a receptor binding assay, we observed that renal cell carcinoma cells expressed a single class of high affinity IL-4R ranging from 1,425 \pm 207 (mean \pm SEM) to $3,831 \pm 299$ (mean \pm SEM) IL-4R molecules/cell with a $K_{d}$ ranging from $112 \pm 11 \mathrm{pM}$ to $283 \pm 71 \mathrm{pM}$. Northern blot analysis for IL-4R gene expression, performed with a cDNA probe to IL-4R, revealed that all RCC cells exhibited a single mRNA species of $4 \mathrm{~kb}$. IL-4 downregulated the surface expression of $I L-4 R$ on one $R C C$ tumor cell line. The function of IL-4R expression on RCC tumor cells was further determined by investigating the effect of IL-4 on tumor cell growth in vitro and comparing it with IL-4 effect on growth of normal fibroblast and endothelial cell lines. Tumor cell growth, as measured by $\left[{ }^{3} \mathrm{H}\right]$ thymidine incorporation, was inhibited by IL-4 from 20 to $68 \%$ in a dose-dependent manner. A neutralizing antibody to human IL-4 was able to reverse the growth inhibitory effect of IL-4. Normal human fibroblast and endothelial cell lines also expressed high affinity IL-4R, however, IL-4 did not inhibit their growth in vitro. In fact, IL-4 caused modest stimulation of their growth. Taken together, our findings can help develop strategies for the treatment of RCC in which IL-4R may be used as a target for IL-4 itself, for IL-4 toxin therapy or, alternatively, in gene therapy. (J. Clin. Invest. 1993. 91:88-93.) Key words: IL-4 receptors on renal cell carcinoma $\bullet$ modulation of IL-4 receptors • tumor cell growth inhibition
\end{abstract}

\section{Introduction}

IL-4 is a glycoprotein product predominantly of Th2 lymphocytes $(1,2)$ and mast cells (3). Although it was originally charac-

Dr. Obiri and Dr. Hillman made equal contributions to the study.

Address correspondence to Raj K. Puri, Ph.D., M. D., Laboratory of Cellular Immunology, Division of Cytokine Biology, Center for Biologics Evaluation and Research, Food and Drug Administration, National Institutes of Health, Building 29A, Room 2B20, Bethesda, MD 20892.

Received for publication 13 March 1992 and in revised form 31 July 1992.

The Journal of Clinical Investigation, Inc.

Volume 91, January 1993, 88-93 terized on the basis of its effects on activated B cells (4), IL-4 has since been shown to have a variety of effects on different cell types. It has been shown to promote survival, growth, and differentiation of both B and T lymphocytes (5-8), mast cells $(9,10)$, and endothelial cells (11). IL-4 affects macrophages by inhibiting the production of tumor necrosis factor, IL-1, and IL-6 $(12,13)$. More recently, IL-4 has also been shown to have antitumor effects in murine models of malignancy (14-16) and to inhibit proliferation of human tumor cell growth in vitro $(17,18)$. Although others have shown that the effect of IL-4 on immune cells are mediated through IL-4 receptor (IL-4R) (19, 20 ), the expression of functional IL-4R on nonlymphoid human tumors has not been described. In a recent study, Puri et al. (21) demonstrated the expression of high affinity IL-4R on murine sarcoma and adenocarcinoma tumor cells. These receptors were capable of internalizing IL-4 after binding to its receptor. In the current study, we have examined primary cultures of human renal carcinoma cells and normal fibroblasts and endothelial cells for the expression of IL-4R. Our results indicate that human renal cell carcinoma $(\mathrm{RCC})^{1}$ cells express mRNA for IL-4R and a single class of high affinity IL-4R on the cell surface. Furthermore, IL-4 caused a decrease in the density of IL-4R and tumor cell proliferation suggesting that antitumor effects may be mediated through downregulation of its own receptors. High affinity IL-4Rs were also expressed on normal human fibroblast and endothelial cell lines, however, IL-4 did not inhibit, but caused a modest stimulation of their growth in vitro.

\section{Methods}

Tumor cells and normal cell lines. Fresh RCC specimens were obtained from Wayne State University (Harper Hospital, Detroit, MI) and from the Surgery Branch, National Cancer Institute (Bethesda, MD) from patients undergoing nephrectomy as part of their medical care. Single cell suspensions of tumors were prepared by digesting minced tumor pieces with $0.002 \%$ deoxyribonuclease, type $1 ; 0.01 \%$ hyaluronidase, type V; and $0.1 \%$ collagenase, type IV (Sigma Chemical Co., St Louis, MO), and used to establish primary cultures. The cells were maintained in complete medium consisting of Dulbecco's modified Eagle medium with $4.5 \mathrm{~g}$ /liter glucose supplemented with $10 \%$ fetal bovine serum, glutamine $(2 \mathrm{mM})$, penicillin $(100 \mathrm{U} / \mathrm{ml})$, and streptomycin $(100 \mu \mathrm{g} /$ $\mathrm{ml}$ ). RCC tumor cells between passages 5 and 20 were used for all experiments. The human Burkitt lymphoma-B cell lines, Molt-4 and Daudi, were kindly provided by Dr. J. A. Hank (University of Wisconsin, Madison, WI). Normal human skin fibroblast cell lines (39-Sk and 969-Sk) and human umbilical vein endothelial (HUVE) cells were obtained from American Type Culture Collection, Rockville, MD.

Cytokines and reagents. Recombinant human IL-4 (sp act $10^{7} \mathrm{U} /$ $\mathrm{mg}$ protein) and an 836-bp cDNA probe for the human IL-4 receptor were a kind gift from Immunex Corp. (Seattle, WA). Rabbit polyclonal

1. Abbreviations used in this paper: HUVE, human umbilical vein endothelial; IL-4R, IL-4 receptor; RCC, renal cell carcinoma. 
antibody to recombinant human IL-4 was purchased from Genzyme Corp. (Boston, MA).

Radioreceptor binding assay. Recombinant human IL-4 was enzymatically labeled with ${ }^{125}$ I (Amersham Corp., Arlington Heights, IL) by the enzymobead method according to manufacturer's instructions (Bio-Rad Laboratories, Richmond, CA). The specific activity of the radiolabeled IL-4 was determined by competition for binding sites of labeled IL-4 with unlabeled IL-4 using the IL-4R-positive gibbon lymphoma cell line, MLA 144 . The specific activity of ${ }^{125}$ I-IL-4 was estimated to range from $6 \times 10^{9}$ to $5 \times 10^{10} \mathrm{cpm} / \mathrm{mg}$ protein.

For IL-4R assays, equilibrium binding studies were performed by the method previously described $(21,22)$. Briefly, $2.5 \times 10^{6} \mathrm{RCC}$ cells in $126 \mu$ l binding buffer (RPMI 1640 containing $0.2 \%$ human serum albumin) were incubated with various concentrations of ${ }^{125} \mathrm{I}-\mathrm{IL}-4$ at $4^{\circ} \mathrm{C}$ in polypropylene tubes in a shaking water bath. For each concentration of ${ }^{125} \mathrm{I}-\mathrm{IL}-4$, nonspecific binding was determined by including 100-200 molar excess of unlabeled IL-4 in duplicate tubes. Cell-bound ${ }^{125} \mathrm{I}-\mathrm{IL}-4$ was separated by centrifugation through a cushion of phthalate oils and counted in a gamma counter. The number of receptors and binding affinities were determined by Scatchard plot analysis of the data (23).

For regulation experiments, PM-RCC tumor cells were cultured with or without IL-4 $(20 \mathrm{ng} / \mathrm{ml})$ for $72 \mathrm{~h}$ at $37^{\circ} \mathrm{C}$. Cells were then harvested and IL-4R determined.

Northern blot analysis. Adherent tumor cells were harvested from tissue culture flasks by brief exposure to versene (Whittaker Bioproducts, Walkersville, MD). After several washes, total RNA was extracted with RNAzol (Cinna/Biotecx Laboratories, Friendswood, TX) in a one-step procedure according to the manufacturer's instructions. $10 \mu \mathrm{g}$ of total RNA were electrophoresed through $1 \%$ agarose/formaldehyde denaturing gel and transferred to a nylon membrane ( $\mathrm{S}$ and $\mathrm{S}$ Nytran; Schleicher and Schuell, Keene, $\mathrm{NH}$ ) by capillary action (24). The nucleic acid was bound to the membrane by ultraviolet cross-linking (Stratagene Inc., La Jolla, CA). After a 12-h prehybridization at $42^{\circ} \mathrm{C}$, the immobilized RNA was allowed to hybridize at $42^{\circ} \mathrm{C}$ for $12 \mathrm{~h}$ with a ${ }^{32} \mathrm{P}$-labeled human IL-4R cDNA probe ${ }^{32} \mathrm{P}$-deoxycytidine was obtained from ICN ImmunoBiologicals, Costa Mesa, CA). Filters were exposed to autoradiographic film for 3-10 d.

Assay for tumor cell growth. Tumor or normal cells were harvested from tissue culture flasks with versene or trypsin and resuspended to a concentration of $5 \times 10^{4}$ cells $/ \mathrm{ml}$ in complete medium. $100 \mu \mathrm{l}$ of this suspension were then plated in quadruplicates in a 96-well flat-bottomed microtiter plate and supplemented with $0-1,000 \mathrm{ng} / \mathrm{ml} \mathrm{IL-4} \mathrm{in}$ $100 \mu \mathrm{l}$. The cultures were incubated at $37^{\circ} \mathrm{C}$ in a $5 \% \mathrm{CO}_{2}$ incubator for 72-96 $\mathrm{h}$ and then labeled with $1 \mu \mathrm{Ci} /$ well $\left[{ }^{3} \mathrm{H}\right]$ thymidine (Amersham Corp.) for $18 \mathrm{~h}$. Cells were harvested onto a glass fiber filter with a harvester (Micromate 196; Packard Instrument Co., Inc., Meriden, CT) using versene. $\left[{ }^{3} \mathrm{H}\right]$ thymidine uptake was determined with a $\beta$ direct counter (Matrix 96; Packard Instrument Co., Inc.).

\section{Results}

Cell surface expression of $I L-4 R$. To investigate the expression and binding affinity of IL-4R, we incubated RCC tumor cells with increasing concentrations of ${ }^{125} \mathrm{I}-\mathrm{IL}-4$ at $4^{\circ} \mathrm{C}$ for $2 \mathrm{~h}$. Representative results from two RCC lines (WS-RCC and GWRCC) are shown in Fig. 1. RCC tumor cells bound IL-4 in a concentration dependent manner (Fig. $1 A$ ). Scatchard plot analysis of the binding data suggested that a single class of high affinity IL-4R were expressed on GW-RCC $\left(K_{d}=112 \pm 11, n\right.$ $=3$ ), WS-RCC $\left(K_{\mathrm{d}}=130 \pm 0, n=2\right)$ (Fig. $\left.1 B\right)$ and PM-RCC tumor cells $\left(K_{\mathrm{d}}=283 \pm 71 \mathrm{pM}\right.$, mean \pm SEM, $\left.n=4\right)$ (not shown). In multiple experiments, the number of IL-4 molecules bound/cell on the PM-RCC tumor cells was 3,831 \pm 299 (mean \pm SEM, $n=4)$, on WS-RCC $2,269 \pm 132(n=2)$, and on GW-RCC tumor cells was $1,425 \pm 207(n=3)$. Other RCC tumor cells also expressed similar number of IL-4R (data not
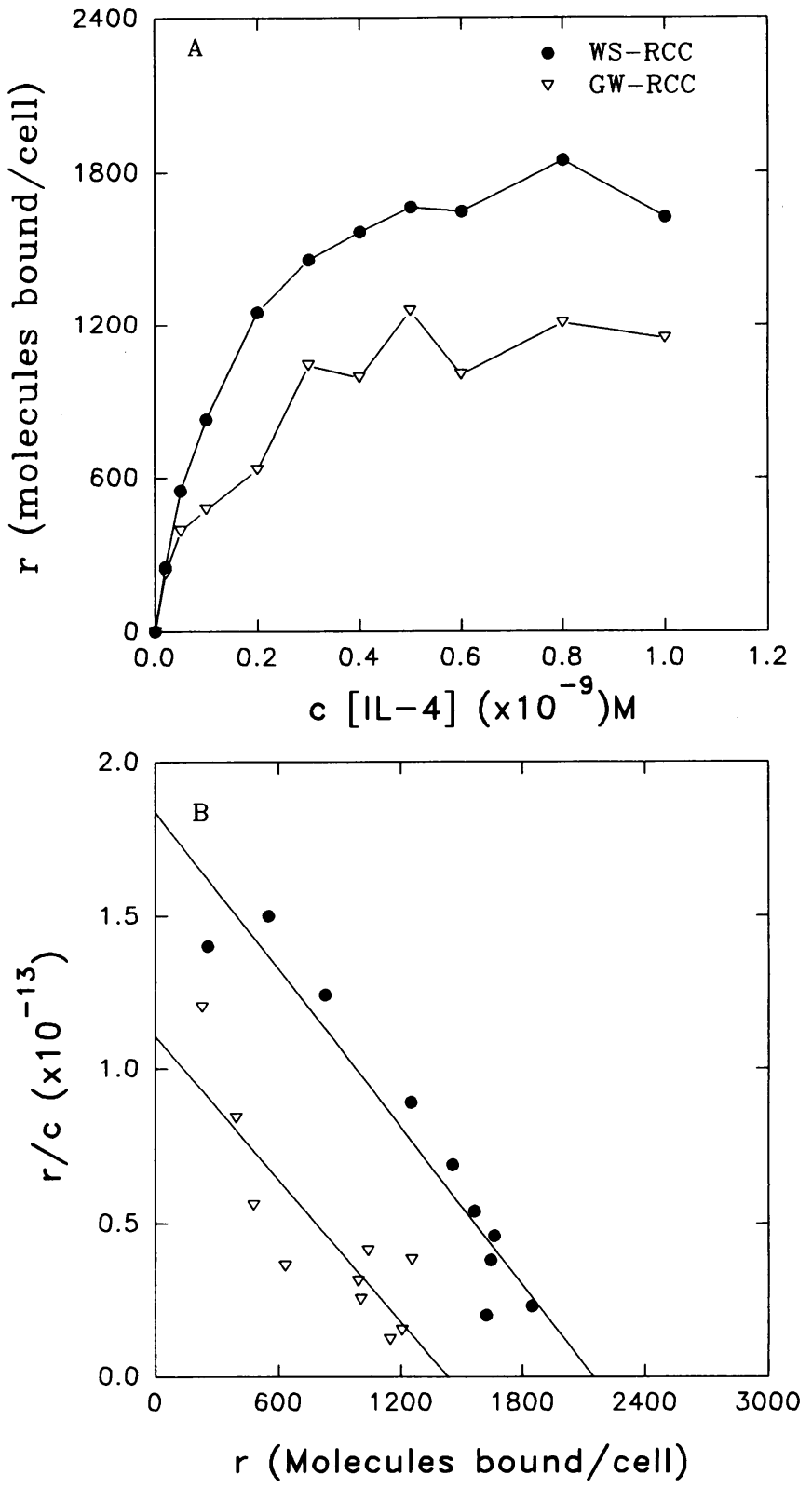

Figure 1. Binding of ${ }^{125} \mathrm{I}-\mathrm{IL}-4$ to human RCC cells. Tumor cells were incubated with $50 \mathrm{pM}-1 \mathrm{nM}{ }^{125} \mathrm{I}-\mathrm{IL}-4$ for $2 \mathrm{~h}$ at $4^{\circ} \mathrm{C}$. In duplicate tubes, 100-200-fold molar excess unlabeled IL-4 was included to determine nonspecific binding. The number of specifically bound ${ }^{125} \mathrm{I}$ IL-4 molecules/cell was determined and used to plot the binding curve shown in $A$ and the Scatchard plot shown in $B$. Data are represented as a single experiment performed in duplicate, representative of two or three separate experiments.

shown). Similar numbers of IL-4 receptors with similar binding affinity have been reported on human $\mathrm{T}$ and $\mathrm{B}$ cell lines (19, 25). Recently we have also observed that human ovarian, breast, and melanoma cell lines express a comparable number and affinity of IL-4R as human RCC cells (unpublished data).

Normal HUVE and skin fibroblast cell lines (969-Sk, 39Sk), as well as Daudi and Molt-4 lymphoblastoid cell lines, were also examined for the expression of IL-4R. The number of IL-4 molecules bound/cell and $K_{\mathrm{d}}$ on these cells are listed in Table I. Normal skin fibroblast, HUVE, and Daudi cells expressed varying numbers of IL-4R, while on Molt- 4 cells, IL- 
Table I. Expression of IL-4 Receptors on Human Normal and Lymphoblatoid Cell Lines

\begin{tabular}{lcc}
\hline \multicolumn{1}{c}{ Cell type } & $\begin{array}{c}\text { IL-4 molecules } \\
\text { bound/cell }\end{array}$ & $K_{\mathrm{d}}\left(\times 10^{-12}\right) \mathbf{M}$ \\
\hline HUVE & $1,457 \pm 62^{*}$ & $\mathrm{ND}^{\ddagger}$ \\
39 Sk (fibroblast) & 331 & 300 \\
Daudi (lymphoblastoid) & 45 & 214 \\
Molt-4 (lymphoblastoid) & Undetectable & Undetectable \\
& &
\end{tabular}

* IL-4 molecules bound/cell were determined by using single saturating concentration of ${ }^{125} \mathrm{IL}-4(800 \mathrm{pM})$. ${ }^{\ddagger} \mathrm{ND}$, not done.

$4 \mathrm{R}$ were not detectable. The affinity of IL-4R on fibroblast and Daudi cell lines was similar to that observed on RCC-tumor cells (Table I).

$I L-4 R$ gene expression. Northern blot analysis of IL-4R gene expression was performed on RCC tumor cells. RNA from CTLL-2 cells, a mouse cytotoxic T cell line, was included as a negative control while RNA from CTLL-2 cells transfected with the human IL-4R cDNA (CTLL-T22-8) (20) was used as a positive control. RNA from CTLL-2 cells did not hybridize with the hIL-4R cDNA probe (Fig. $2 A$, lane 1 ) while RNA from the IL-4R transfected cell line did (Fig. 2, lane 2). All tested RCC tumor cell lines expressed a high density of single species of mRNA (size: $4.0 \mathrm{~kb}$ ) for hIL-4R (Fig. $2 A$, lanes 3-5).

We also examined the mRNA expression for IL-4R on Daudi and Molt- 4 cells. As depicted in Fig. 2 B, only CTLL-2T22-8 cells (lane 1) and Daudi cells (lane 2) expressed the mRNA for IL-4R, however, we did not observe any hybridization with Molt-4 RNA (Fig. 2 , lane 3).

Effect of IL-4 on tumor cell growth. To determine the functional significance of the expression of high affinity IL-4R on RCC tumor cells, we tested the effect of IL-4 on the growth of these cells in tissue culture. We found that IL-4 caused a direct antiproliferative effect of varying degree on RCC tumor cells isolated from several patients. This tumor growth inhibition mediated by IL-4 was dose dependent (Fig. $3 \mathrm{~A}$ ). Maximum inhibition of PM-RCC and GW-RCC tumor cell growth $(\sim 50 \%)$ was observed at IL-4 concentration of $10-100 \mathrm{ng} / \mathrm{ml}$ (Fig. $3 \mathrm{~A}$ ), while no further inhibition was observed at higher concentrations (100-1,000 ng/ml) (Fig. 4). IL-4-mediated growth inhibition was reproducible and observed in other RCC tumor lines. IL-4 at $10 \mathrm{ng} / \mathrm{ml}$ inhibited the growth of RG-RCC, TR-RCC, and SJ-RCC, by 68,31 , and $39 \%$, respectively. Although Daudi cells have been shown to express IL-4R $(19,25)$, the growth inhibitory effect of IL-4 was not observed in these cells (Fig. $3 A$ ) indicating that the IL-4 effect is cell type specific.

The level of inhibition of RCC tumor cell growth as determined by cell counts at the end of 7-d culture with IL- 4 was comparable to that observed with $\left[{ }^{3} \mathrm{H}\right]$ thymidine uptake. However, cell viability (as determined by trypan blue exclusion) was $100 \%$ in both IL-4-treated and untreated groups (data not shown). These data indicate that IL-4 caused cytostatic rather than cytotoxic effects on RCC tumor cells.

To establish that the observed growth inhibitory effects were mediated directly by IL-4, we investigated the effect of a neutralizing antibody directed against human IL-4 on RCC tumor cell proliferation. We found that anti-IL-4 antibody reversed the growth inhibition caused by IL-4 in a concentrationdependent manner (Fig. $3 \mathrm{~B}$ ). At $10 \mu \mathrm{g} / \mathrm{ml}$, the anti-IL-4 antibody significantly neutralized the antiproliferative effects of
IL-4 $(P<0.03)$, however, complete neutralization was not observed. Thus our data corroborate previous findings (18) and further suggest that the antiproliferative effects of IL-4 are mediated through its receptors.

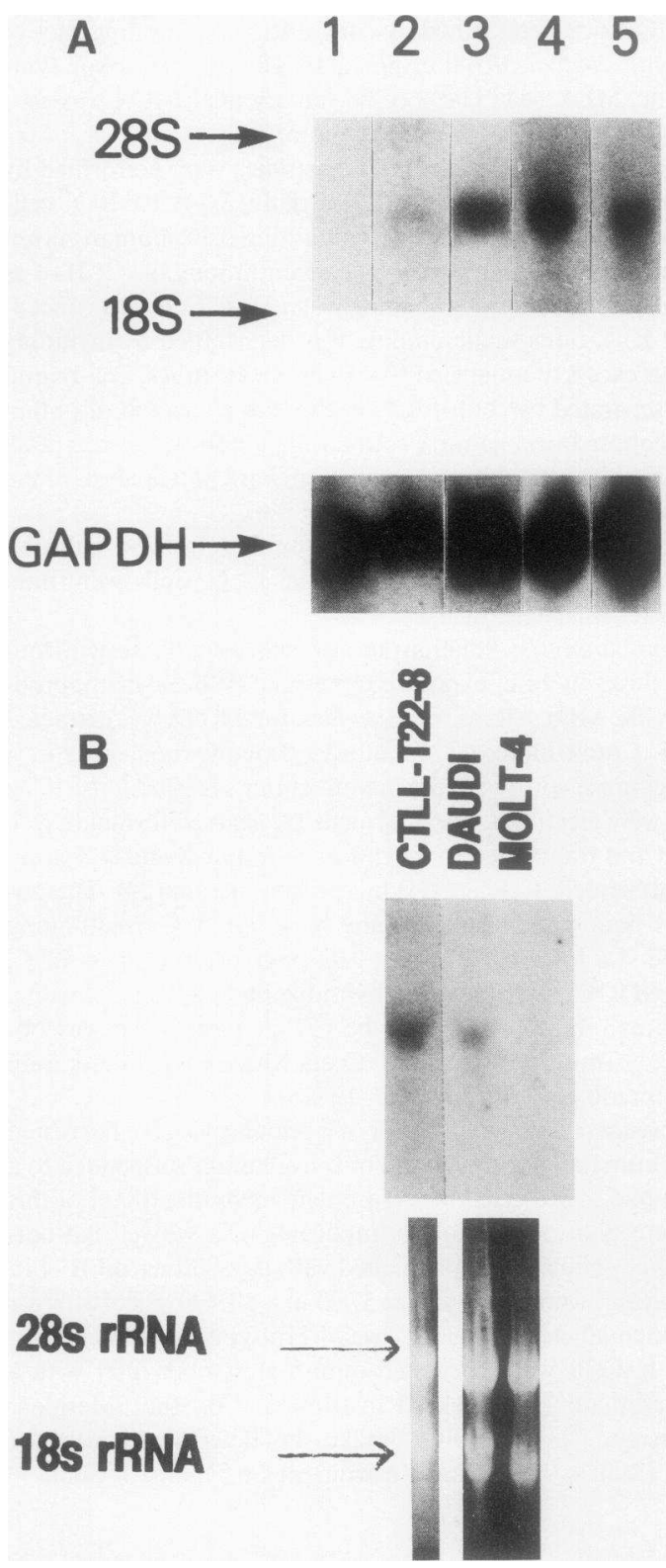

Figure 2. (A) Expression of IL-4R mRNA by human RCC cells. Total RNA was isolated from RCC cells, and a 10- $\mu \mathrm{g}$ sample from each was electrophoresed and then transferred to a nylon filter. The immobilized RNA was analyzed with a ${ }^{32} \mathrm{P}$-labeled cDNA probe for human IL4R. RNA from a mouse T cell line CTLL-2 before and after transfection with the human IL-4R gene (CTLL-T22-8) were included as controls (lanes 1 and 2, respectively). Lanes 3-5 represent gene expression from different RCC cells (lane 3, WS-RCC; lane 4, HLRCC; lane 5, PM-RCC). For internal standard the blots were rehybridized with ${ }^{32} \mathrm{P}$-labeled CDNA probe for GAPDH and shown in the figure (lower panel). (B) Expression of IL-4R mRNA on Daudi and Molt-4 cells. Total RNA $(20 \mu \mathrm{g})$ from Daudi, Molt-4, and CTLLT22-8 was electrophoresed and analyzed for the expression of IL-4R mRNA as described in $A$. Lane 1, CTLL-T22-8; lane 2, Daudi; and lane 3, Molt-4 cell-derived RNA. Lower panel represents ethidium bromide staining of rRNA which indicates that an equivalent amount of RNA was loaded in each lane. 

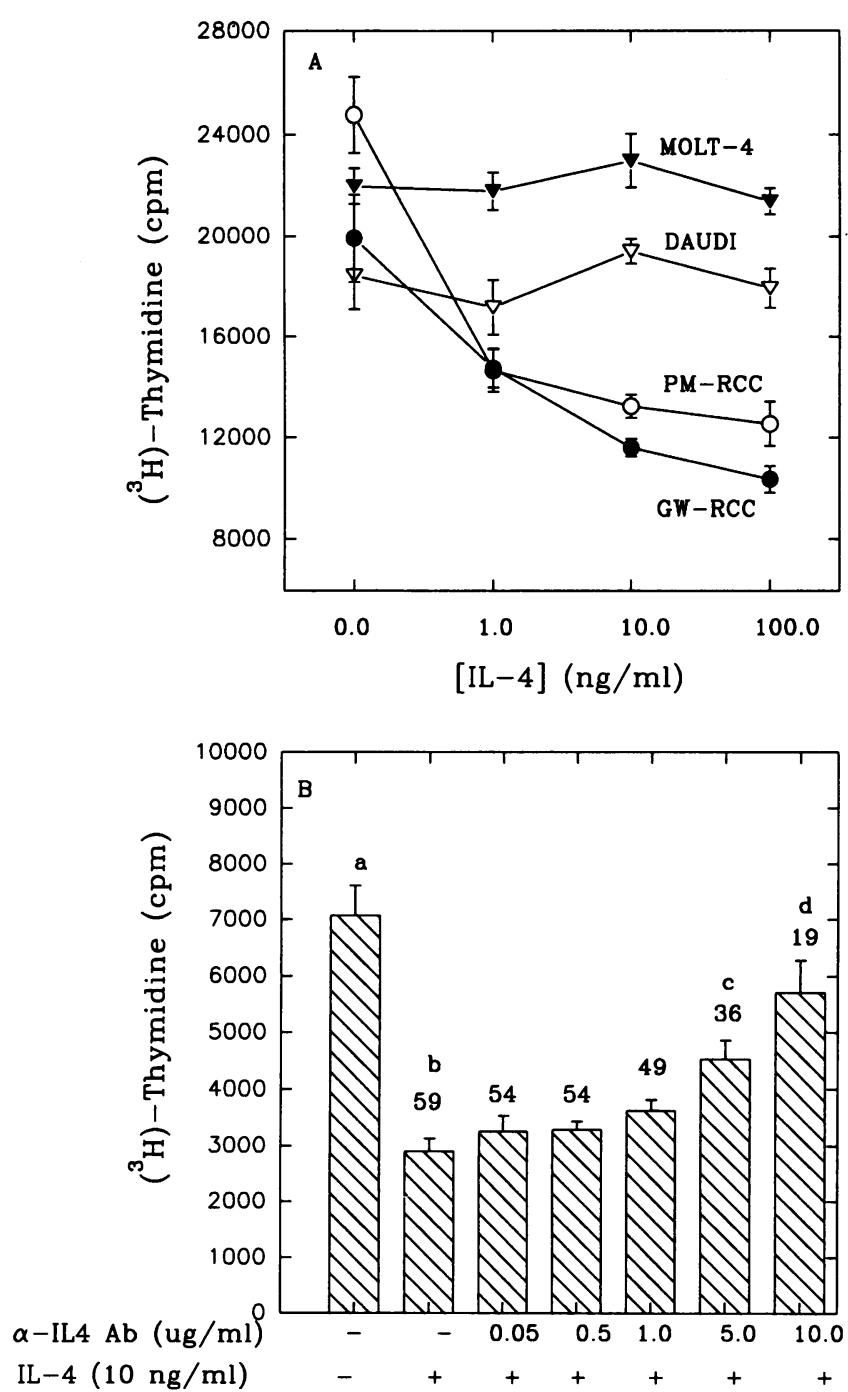

Figure 3. IL-4 inhibits RCC tumor cell growth in vitro. PM-RCC, GW-RCC, Molt-4, or Daudi cells, at a concentration of $5 \times 10^{3} /$ well, were cultured with various concentrations of IL-4 for $3-4 \mathrm{~d}$ at $37^{\circ} \mathrm{C}$ and labeled for $18 \mathrm{~h}$ with $\left[{ }^{3} \mathrm{H}\right]$ thymidine as described in Methods $(A)$. GW-RCC tumor cells were cultured with or without $10 \mathrm{ng} / \mathrm{ml} \mathrm{IL-4}$ in the presence of increasing concentrations of anti-IL-4 antibody for $3 \mathrm{~d}(B)$. Data are reported as the mean $\mathrm{cpm} \pm \mathrm{SD}$ of quadruplicate wells. The numbers shown above the bars in $B$ indicate the percent growth inhibition relative to growth in control cultures in which cells were incubated in medium alone. Letters above the bars represent statistical analysis of data by Student's $t$ test and the levels of significance are as follows: a vs b, $P<0.0001$; b vs c, $P<0.001$; b vs d, $P$ $<0.001$; a vs c, $P<0.001$; a vs d, $P<0.03$.

Effect of IL-4 on normal cell lines. To understand the significance of growth inhibitory effects of IL-4 on RCC tumor cells, we tested the effects of IL-4 on the growth of normal cell lines. Two normal human skin fibroblasts cell lines (969-Sk and 39Sk) were used in a 4-d proliferation assay and their proliferation was compared to that of RCC tumor cells. IL-4 caused modest stimulation of growth of normal skin fibroblast cells (Fig. 4). At $1 \mathrm{ng} / \mathrm{ml}$, IL-4 caused a modest stimulation of growth of both fibroblast cell lines and this growth stimulation was statistically significant compared to that of control untreated cells $(P<0.001)$. Similarly, the stimulation of normal HUVE cells and human adrenal capillary endothelial (HACE)

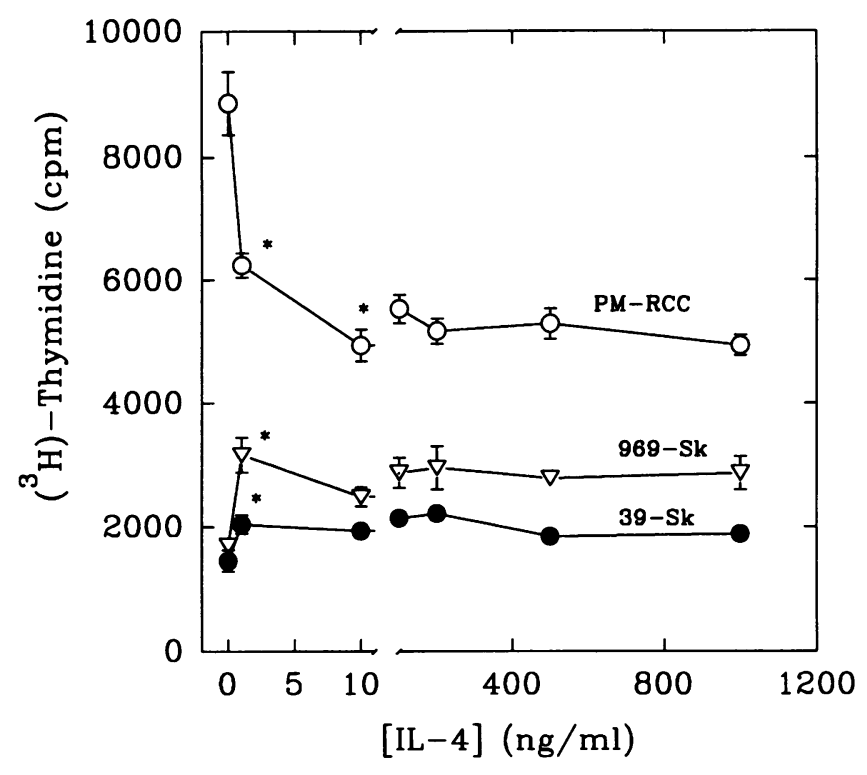

Figure 4. IL-4 stimulates growth of human normal skin fibroblast cell lines in vitro. $5 \times 10^{3}$ fibroblast cell lines (969-Sk and $39 \mathrm{Sk}$ ) and RCC tumor cells (PM-RCC) were cultured in the presence of indicated concentrations of IL-4 for $3 \mathrm{~d}$ at $37^{\circ} \mathrm{C}$ and labeled for $18 \mathrm{~h}$ with $\left[{ }^{3} \mathrm{H}\right]$ thymidine as described in Methods. Data are represented as mean cpm \pm SD of quadruplicate samples. Asterisks represent statistical analyses which indicate that data is highly significant $(P<0.001$ for PM-RCC, 969-Sk, and $P<0.01$ for 39-Sk) from respective control (cells cultured in medium alone) groups.

cells have previously been reported (11). In contrast, IL-4 caused the inhibition of PM-RCC tumor cell growth in a dosedependent manner (Fig. 4). These data further indicate the significance of our observations and confirm cell type-specific effects of IL-4 on growth inhibition.

Regulation of $I L-4 R$ by $I L-4$. To understand the mechanism of inhibition of tumor cell growth by IL-4, we investigated the regulation of IL-4R by IL-4. PM-RCC cells were cultured with or without IL-4 $(20 \mathrm{ng} / \mathrm{ml})$ for a 4-72-h period. Cells were then harvested using versene and the expression of IL-4R and its affinity were determined by equilibrium binding and Scatchard plot analysis. IL-4 significantly downregulated its receptors after $4 \mathrm{~h}$ of incubation (data not shown) and this down regulation was optimal after $72 \mathrm{~h}$ of incubation. ${ }^{125} \mathrm{IL}-4$ specifically bound to RCC tumor cells in a concentration-dependent manner but this binding was significantly decreased after 72-h treatment with IL-4 (Fig. 5 A). Scatchard plot analysis of the binding data revealed that the density of IL-4 receptors was decreased from $2,957 \pm 703(n=2)$ IL-4R molecules/ cell on untreated cells to $1,298 \pm 645(n=2)$ IL-4R molecules/ cell on treated cells (Fig. $5 \mathrm{~B}$ ). However, the dissociation constant in IL-4 treated cells $(98 \pm 19 \mathrm{pM})$ was similar to that of untreated cells $(94 \pm 14 \mathrm{pM})$.

\section{Discussion}

In this study, we demonstrate that RCC tumor cells express high affinity IL-4R. The expression of high affinity IL-4R on human RCC tumor cells has not been previously reported. Our results demonstrate the expression of IL-4R at the protein and gene level. The IL-4R appear to be functional as IL-4 was able 

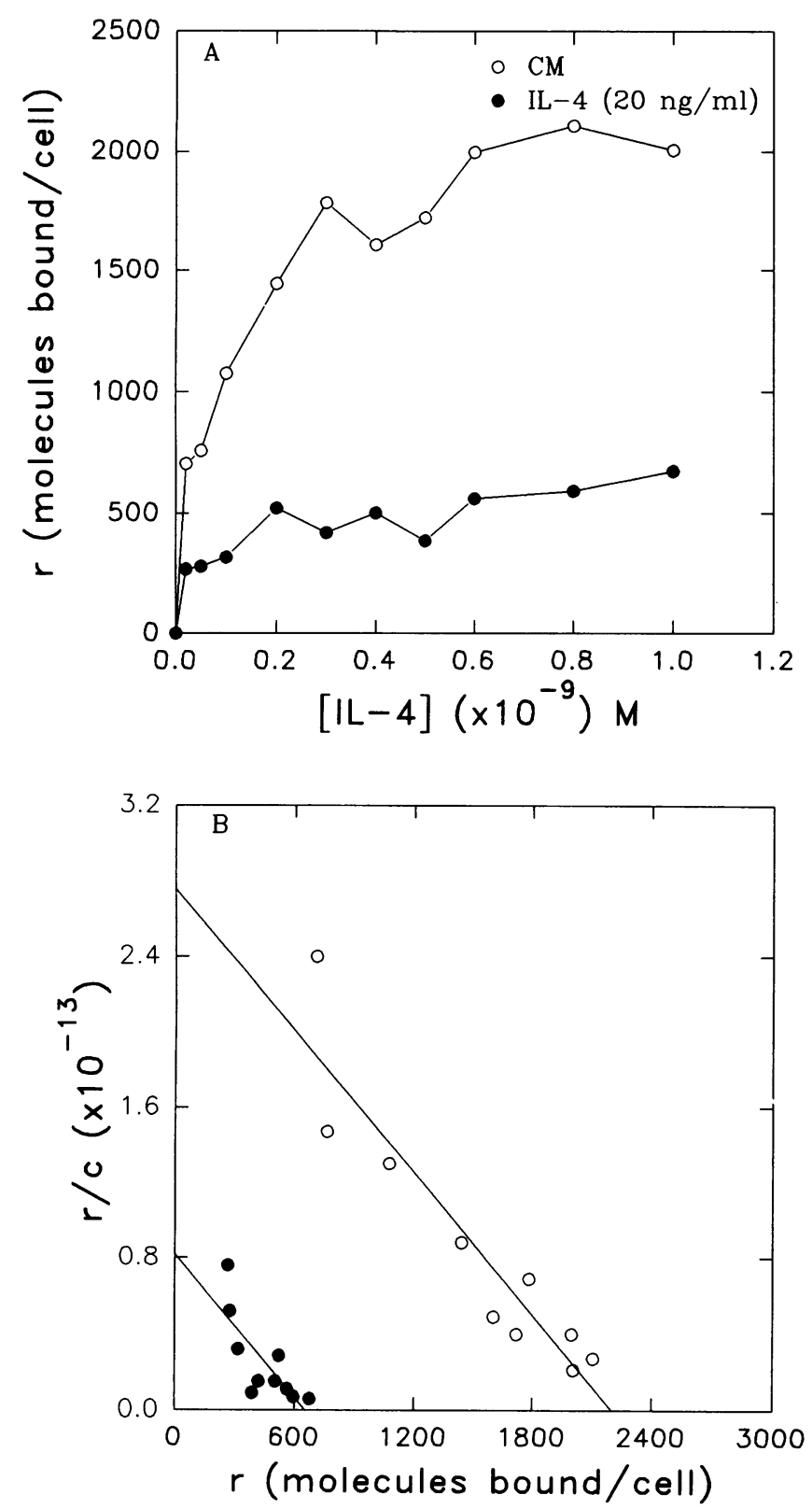

Figure 5. IL-4 inhibits IL-4 R on human RCC tumor cells. Tumor cells (PM-RCC) were cultured with or without IL-4 $(20 \mathrm{ng} / \mathrm{ml})$ for $72 \mathrm{~h}$. Cells were then harvested, washed, and stripped to remove excess IL-4, and further incubated with $50 \mathrm{pM}-1 \mathrm{nM}^{125} \mathrm{I}-\mathrm{IL}-4$ for $2 \mathrm{~h}$ at $4^{\circ} \mathrm{C}$. In duplicate tubes, 100-200-fold molar excess unlabeled IL-4 was included to determine nonspecific binding. The number of specifically bound ${ }^{125} \mathrm{I}-\mathrm{IL}-4$ molecules/cell was determined and used to plot the binding curve shown in $A$ and the Scatchard plot shown in $B$. Data are represented as a single experiment performed in duplicate and representative of two separate experiments.

to inhibit RCC tumor cell growth in vitro. A neutralizing antibody to IL-4 was able to abrogate the growth inhibitory effects of IL-4.

The role of IL- $4 \mathrm{R}$ on hurhan RCC tumor cells is not known. IL-4R may have some regulatory role in tumor cell growth in vivo. Previous studies have suggested that IL-4R may be associated with an oncogene or may itself be a novel oncogene (26). However, these possibilities are unlikely because our studies and those of others $(17,18)$ show that IL-4 has antiproliferative effects on tumor cells.
Recently, IL-4 has also been shown to inhibit the growth of human hematopoietic cell derived tumors such as multiple myeloma, lymphoma (27), and chronic myelomonocytic leukemia cells (28). Moreover, IL-4 increased the antiproliferative effects mediated by tumor necrosis factor on various human tumor lines including breast carcinoma, epidermoid carcinoma, and histiocytic lymphoma cells (29). Thus our data agree with published reports on growth inhibitory function of IL-4.

Interestingly, in contrast to the inhibition of RCC tumor cell growth, IL-4 did not inhibit the growth of control Molt-4 and Daudi lymphoblastoid cell lines (Fig. 3). Molt-4 cells did not express IL-4R at the mRNA level or on the cell surface consistent with the lack of IL-4 effect on these cells. However, Daudi cells did express IL-4R mRNA but expressed a lower number of IL-4R on cell surface ( $<100$ molecules bound/cell) (Table I) compared to RCC tumor cells (Fig. 1). Daudi cell lines have been shown to express varying number of IL-4R, however, receptor numbers observed in our studies were lower than those observed previously $(19,25)$. Difference in cell lines may explain this difference. Thus lower numbers of IL-4R present on Daudi cells might explain the lack of IL-4 effect on these cells.

The mechanism for IL-4 unresponsiveness on Daudi and Molt- 4 cells based on receptor number/cell cannot be explained in the light of data obtained with normal cells. Normal fibroblast and endothelial cells expressed a higher number of IL-4 receptors than Daudi cells, however, in contrast to data observed on RCC tumor cells, IL-4 caused a modest growth stimulation of normal cells. These data are in agreement with a published report in which IL-4 has been shown to be a mitogen for normal HUVE and human adrenal capillary endothelial cell lines (11). IL-4 has also been shown to be a growth factor for murine normal fibroblast cell lines (30), however, its effects on the growth of normal human fibroblast cells has not been reported. We observed a modest but significant growth-stimulatory effect of low concentration of IL-4 on two human normal fibroblast cell lines (Fig. 4).

We considered that the difference in receptor affinities may account for differences in IL-4 response in various cell types. However, we have found that the $K_{\mathrm{d}}$ was not different on normal, lymphoblastoid, and RCC tumor cells. These different cell types might differ in the mechanisms of receptor internalization, processing, and/or signal transduction triggered by IL4 binding to its receptors. Irrespective of the mechanism of action, our data suggest that IL-4 may be a useful agent for the regulation of RCC tumor growth in vivo without mounting inhibitory effects on normal cells.

Our data also demonstrate that IL-4 can downregulate its own receptors. Transient downregulation of IL-4R by IL-4 on human Jijoye cell line has been previously reported (31). However, on resting T and B lymphocytes IL- 4 has been shown to upregulate its receptors (32). The significance of downregulation of IL-4R by IL- 4 on human RCC tumor cells remains to be determined. It is possible that the downregulation of IL-4R may be involved in the mechanism of inhibition of tumor growth by IL-4.

IL-4 has also been shown to upregulate classes I and II HLA antigens on some tumor cells including RCC cells $(17,18)$. In murine studies perilymphatic administration of low doses of IL- 4 has been shown to cause the rejection of established tumors by host immune cells (14). Furthermore, murine tumor 
cells transduced with IL-4 gene can abrogate the growth of tumor cells in vivo (15) or cause the regression of established tumor at a distant site due to enhanced tumor immunogenicity and enhancement of CTL response (16). These findings, particularly, in a murine experimental model for RCC using IL-4 transduced Renca tumor cells (16), reinforce the importance of our data demonstrating the expression of functional IL-4R on human RCC tumor cells. Taken together, these observations can help develop strategies for the treatment of human RCC in which IL-4R may be used as a target for IL-4 itself, IL-4 toxin therapy, or, alternatively, in gene therapy (16).

\section{Acknowledgments}

We thank Drs. Gary Weiss and Marston Linehan of the Surgery Branch, National Cancer Institute, Bethesda, MD for providing some RCC samples, and Patricia Beckmann and Steven Gillis of Immunex Corp. for providing IL-4 and cDNA for IL-4R and a CTLL-T22-8 cell line transfected with human IL-4R. We also thank Drs. Jay Siegel and David Finbloom of the FDA for critical reading of the manuscript.

This work was done while N. I. Obiri held a National Research Council-National Institutes of Health, Center for Biologics Evaluation and Research, Research Associateship. The study was also supported in part by American Cancer Society grant IN-162-C.

\section{References}

1. Mossmann, T. R., H. Cherwinski, M. W. Bond, M. A. Giedlin, and R. L. Coffman. 1986. Two types of murine helper $T$ cell clones. Definition according to profiles of lymphokine activities and secreted proteins. J. Immunol. 136:23482357.

2. Milanese, C., N. E. R. Richardson, and E. L. Reinherz. 1986. Identification of $\mathrm{T}$ helper cell-derived lymphokine that activates resting $\mathrm{T}$ lymphocytes. Science (Wash. DC). 231:1118-1122.

3. Plaut, M., J. H. Pierce, C. J. Watson, J. H. Hyde, R. P. Nordan, and W. E. Paul. 1989. Mast cell lines produce lymphokines in exposure to cross lineage of $\mathrm{FC} \epsilon \mathrm{R} 1$ or to calcium ionophores. Nature (Lond.). 6219:64-67.

4. Howard, M., J. Farrar, M. Hilfiker, B. Johnson, K. Takatsu, T. Hamaoka and W. E. Paul. 1982. Identification of a T cell-derived B cell growth factor distinct from IL-2. J. Exp. Med. 155:914-923.

5. De France, T., T. Vanbervliet, J. P. Aubrey, Y. Takebe, N. Arai, A. Miyajima, T. Yokota, F. Lee, K. I. Arai, J. E. DeVries, and J. Banchereau. 1987. B cell growth promoting activity of recombinant human interleukin 4. J. Immunol. 139:1135-1144.

6. Brown, M., J. Hu-Li, and W. E. Paul. 1988. IL-4/B cell stimulatory factor-1 stimulates $\mathrm{T}$ cell growth by an IL-2 independent mechanism. J. Immunol. 131:504-511.

7. Coffman, R. L., J. Ohara, M. W. Bonds, J. Carty, A. Zlotnik, and W. E. Paul. 1986. B cell stimulatory factor-1 enhances IgE response of lipopolysaccharide-activated B cells. J. Immunol. 136:4538-4541.

8. Horohov, D. W., J. A. Crim, P. Smith, and J. P. Siegel. 1988. IL-4 (B cell stimulatory factor 1) regulates multiple aspects of influenza virus specific cell-mediated immunity. J. Immunol. 141:4217-4223.

9. Hamaguchi, Y., Y. Kanakura, J. Fujita, S. I. Takeda, T. Nakano, S. Tarui, T. Honjo, and Y. Kitamura. 1987. Interleukin 4 as an essential factor for in vitro clonal growth of murine connective tissue-type mast cells. J. Exp. Med. 165:268273.

10. Mossman, T. R., M. W. Bond, R. L. Coffman, J. Ohara, and W. E. Paul. 1986. T-cell and mast cell lines respond to B-cell stimulatory factor-1 Proc. Natl. Acad. Sci. USA. 83:5654-5658.
11. Toi, M., A. L. Harris, and R. Bicknell. 1991. Interleukin 4 is a potent mitogen for capillary endothelium. Biochem. Biophys. Res. Commun. 174:12871293.

12. Hart, P. H., G. F. Vitti, D. R. Burgess, G. A. Whitty, D. S. Piccoli, and J. A-Hamilton. 1989. Potential antiinflammatory effects of interleukin 4: suppression of human monocyte, tumor necrosis factor $\alpha$, interleukin 1, and prostaglandin $\mathrm{E}_{2}$. Proc. Natl. Acad. Sci. USA. 86:3803-3807.

13. Lee, J. D., S. G. Swisher, E. H. Minehart, W. H. McBride, and J. S. Economou. 1990. Interleukin-4 downregulates interleukin 6 production in human peripheral blood mononuclear cells. J. Leukocyte Biol. 47:475-479.

14. Bosco, M., M. Giovarelli, M. Forni, A. Modesti, S. Scarpa, L. Masuelli, and G. Forni. 1990. Low doses of IL4 injected perilymphatically in tumor-bearing mice inhibit the growth of poorly and apparently nonimmunogenic tumors and induce a tumor-specific immune memory. J. Immunol. 145:3136-3243.

15. Tepper, R. I., P. K. Pattengale, and P. Leder. 1989. Murine interleukin 4 displays potent antitumor activity in vivo. Cell. 57:503-512.

16. Golumbeck, P. T., A. J. Lazenby, H. I. Levitsky, L. M. Jaffee, H. Karasuyama, M. Baker, and D. M. Pardoll. 1991. Treatment of established renal cancer by tumor cells engineered to secrete interleukin-4. Science (Wash. DC). 254:713-716.

17. Hoon, D. S. B., M. Banez, E. Okun, D. L. Morton, and R. F. Irie. 1991 Modulation of human melanoma cells by interleukin- 4 and in combination with $\gamma$-interferon or $\alpha$-tumor necrosis factor. Cancer Res. 51:2002-2008.

18. Hoon, D. S. B., E. Okun, M. Banez, R. F. Irie, and D. L. Morton. 1991. Interleukin 4 alone and with $\gamma$-interferon or $\alpha$-tumor necrosis factor inhibits cell growth and modulates cell surface antigens on human renal cell carcinomas. Cancer Res. 51:5687-5693.

19. Park, L. S., D. Friend, and H. M. Sassenfeld. 1987. Characterization of the human B cell stimulatory factor 1 receptor. J. Exp. Med. 166:476-488.

20. Idzerda, R. L., C. J. March, B. Mosley, S. D. Lyman, T. V. Bos, S. D. Gimpel, W. S. Din, K. H. Grabstein, M. B. Widmer, L. S. Park, et al. 1990 Human interleukin 4 receptor confers biological responsiveness and defines a novel receptor superfamily. J. Exp. Med. 171:861-873.

21. Puri, R. K., M. Ogata, P. Leland, G. M. Feldman, D. Fitzgerald, and I. Pastan. 1991. Expression of high-affinity interleukin 4 receptors on murine sarcoma cells and receptor-mediated cytotoxicity of tumor cells to chimeric protein between interleukin 4 and Pseudomonas exotoxin. Cancer Res. 51:3011-3017.

22. Puri, R. K., D. S. Finbloom, P. Leland, M. Mostowski, and J. P. Siegel. 1990. Expression of high affinity IL -4 receptors on murine tumor infiltrating lymphocytes and their upregulation by IL-2. Immunology. 70:492-497.

23. Scatchard, G. 1949. The attractions of proteins for small molecules and ions. Ann. NY Acad. Sci. 51:660-663.

24. Sambrook, J., E. F. Fritsch, and T. Maniatis. 1989. Molecular Cloning: A Laboratory Manual. Cold Spring Harbor Laboratory, Cold Spring Harbor, NY.

25. Cabrillat, H., J. Galizzi, O. Djossou, N. Arai, T. Yokota, and J. Banchereau. 1986. High affinity binding of human interleukin 4 to cell lines. Biochem. Biophys. Res. Commun. 149:995-1001.

26. Jabaari, B. A., H. M. Ladyman, M. Larche, G. B. Sivolapenko, A. A. Epenetos, and M. A. Ritter. 1989. Elevated expression of the interleukin 4 receptor in carcinoma: a target for immunotherapy. Br. J. Cancer. 59:910-914.

27. Taylor, C. W., T. M. Grogan, and S. E. Salmon. 1990. Effects of interleukin-4 on the in vitro growth of human lymphoid and plasma cell neoplasms. Blood. 75:1114-1118.

28. Akashi, K., T. Shibuya, M. Harada, Y. Takamatsu, N. Uike, T. Eto, and Y. Niho. 1991. Interleukin-4 suppresses the spontaneous growth of chronic myelomonocytic leukemia cells. J. Clin. Invest. 88:223-230.

29. Totpal, K., and B. B. Aggarwal. 1991. Interleukin 4 potentiates the antiproliferative effects of tumor necrosis factor on various tumor cell lines. Cancer Res. 51:4266-4270.

30. Monroe, J. G., S. Halda, M. B. Prystowsky, and P. Lammie. 1988. Lymphokine regulation of inflammatory processes: IL-4 stimulates fibroblast proliferation. Clin. Immunol. Immunopathol. 49:292-298.

31. Galizzi, J-P., C. E. Zuber, H. Cabrillat, O. Djossou, and J. Banchereau. 1989. Internalization of human interleukin 4 and transient down-regulation of its receptor in the CD-23 inducible Jijoye cells. J. Biol. Chem. 264:6984-6989.

32. Ohara, J., and W. E. Paul. 1988. Up-regulation of interleukin 4/B-cell stimulatory factor 1 receptor expression. Proc. Natl. Acad. Sci. USA. 85:82218225 . 